\title{
Valuation through EVA and Traditional Measures an Empirical Study
}

\author{
*Dr. N R V Ramana Reddy, IACSIT Member, **M.Rajesh, IACSIT Member and ***Dr.T.Narayana \\ Reddy
}

\begin{abstract}
Profit maximization as a concept is age-old, wealth maximization is matured and value maximization is today's wisdom. Economic Value Added (EVA) is one such innovation. Unlike traditional accounting measures of performance, EVA attempts to measure the value that firms create or destroy by subtracting a capital charge from the cash returns they generate on invested capital. Besides the measures like Return on Equity (ROE), Return on Net worth (RONW), Return on Capital Employed (ROCE) and Earnings per Share (EPS), EVA is a new measure available to the corporate managers. It combines factors such as economy, accounting and market information in its assessment. This paper describes and compares the EVA with other measures. Apart from this, taking the real financial data of a company, the paper shows how EVA calculations can be done to demonstrate whether the company is adding to shareholder value by generating profits over and above the capital charge. From the analysis it was found that EVA is the best appropriate measure for measuring the value of shareholders.
\end{abstract}

Index Terms-Earnings per share (EPS), Economic Value Added (EVA), Return on Capital Employed (ROCE) and Return on Net worth (RONW).

\section{INTRODUCTION}

Under conventional accounting, most companies appear profitable but many in fact are not. As Peter Drucker put the matter in a Harvard Business Review article, "Until a business returns a profit that is greater than its cost of capital, it operates at a loss. Never mind that it pays taxes as if it had a genuine profit. The enterprise still returns less to the economy than it devours in resources...until then it does not create wealth; it destroys it." Company may intentionally pay tax to prove that they have made profit for their shareholders and thus a falsification is done with owners that is not a rare corporate practice. EVA corrects this error by explicitly recognizing that when managers employ capital they must pay for it, as if it were a wage. It also adjusts all distortions that are very much prevalent in the information generated by conventional accounting. Thus, it is the most demanded tool for the owners in every situation.

\footnotetext{
*Principal, Annamacharya P.G. College of Management Studies, Rajampet, Kadapa, A.P

**AssociateProfessor, Annamacharya, P.G.College of Computer Studies, Rajampet

***Head, Department of MBA, JNTU, Pulivendula, Kadapa, A.P

Emai: raaz.mba@gmail.com.
}

\section{A. The Concept of EVA}

In 1990 a new device was formulated to gauge the profitability of a concern, which is known as 'EVA'. This concept is, as a matter of fact, a reversion to the formulation of Alfred Marshal (1890) which he put forward in early nineteenth century. The EVA of the company is just a measure of the incremental return that the investment earns over the market rate of return. In simple terms, it can be stated that EVA measures the profitability net of cost of capital. As someone has aptly remarked, 'you only get richer if you invest money at a higher return than the cost of money to you'. Everybody knows this but many seem to forget it. Thus, EVA can be taken as the net operating profit minus an appropriate charge for the opportunity cost of all the capital invested in an enterprise. As such, EVA is an estimate of true economic profit or the amount by which earnings exceed or fall short of the required minimum rate ofreturn that shareholder and lenders could get by investing in other securities of comparable risk.

\section{B. EVA Vs Traditional Performance Measures}

The development of the concept of EVA has added flexibility in measurement of

Performance. The traditional methods can continue side by side with EVA. Some of the traditional ways of measuring corporate performance are described here.

\section{Return on Capital Employed (ROCE)}

Return on capital Employed is a very good and relatively good performance measure. Different companies calculate this return with different formulae and call it also with different names like return on invested capital, return on Investment, return on net assets, return on assets etc. The main shortcoming with all these rates of return is that in all cases

Maximizing rate of return does not necessarily maximize the return to shareholders.

\section{Return on Net worth (RONW)}

The level of RONW does not tell the owners if company is creating shareholders' wealth or destroying it. With RONW, this shortcoming is much more severe than with ROI, because simply increasing leverage can increase the ROE. In other words, decreasing solvency does not always make shareholders' position better because of the increased financial risk.

\section{E. Earnings per Share (EPS)}

EPS is raised simply by investing more capital in business. 
If the additional capital is equity (retained earnings) then the EPS will rise if the rate of return of the invested capital is just positive. For example, let us assume that as on March 31, 1999, company A has net worth of Rs 50 million and 5 million equity shares. At a profit after tax of Rs 100 million for FY 1999, the EPS would work out to be 20. The entire income can be ploughed back in the business at a marginal return of $5 \%$. Assuming that the return on previous net worth remains the same, the profit after tax would be Rs 105 million and EPS would be 21. Though the performance has gone down, the EPS has increased. If the additional capital is debt then the EPS will rise if the rate of return of the invested capital is just above the cost of debt. In reality, the invested capital is a mix of debt and equity and the EPS will rise if the rate of return on the additional investment is somewhere between the cost of debt and zero. Therefore EPS is completely inappropriate measure of corporate performance and still is very common yardstick and even a common bonus base.

Unlike conventional profitability measures, EVA helps the management and other employees to understand the cost of equity capital. At least in big companies, which do not have a strong owner, shareholders have often been perceived as free source of funds. These flaws are taken care of by the concept of economic value added. The key feature of this concept is that for the first time any measure takes cares of the opportunity cost of capital invested in business.

Comparison of different Traditional Performance Measures

\begin{tabular}{|c|c|c|c|}
\hline $\begin{array}{c}\text { Performance } \\
\text { Measure }\end{array}$ & \multicolumn{3}{|c|}{ Computation includes } \\
\cline { 2 - 4 } & Returns & $\begin{array}{l}\text { Capital } \\
\text { employed(CE) }\end{array}$ & $\begin{array}{l}\text { Cost of } \\
\text { CE }\end{array}$ \\
\hline NOPAT & YES & NO & NO \\
\hline ROCE & YES & YES & NO \\
\hline RONW & YES & YES & NO \\
\hline EPS & YES & YES & NO \\
\hline
\end{tabular}

From the above table, it is clear that traditional measure of corporate performance does not consider cost of capital in calculation of NOPAT whereas EVA includes the same.

\section{REVIEW OF LITERATURE}

A number of studies have been conducted to establish the relationship between EVA and traditional accounting measures.

\section{A. Stern's comparison of EVA with popular accounting measures}

Stern ${ }^{1}$ (1993:36) argues that the key operating measure of corporate performance is not Popular accounting measures such as earnings, earnings growth, dividends, and dividend Growth, ROE, or even cash flow, but in fact EVA. The changes in the market value of a selected group of companies (specifically their MVAs) have been shown to have a relatively low correlation with the above accounting measures. His research showed that the $\mathrm{r}^{2}$ for the relationship between MVA and various independent variables ranged from $9 \%$ for turnover growth to $25 \%$ for ROE rates. By comparison, the $r^{2}$ for EVA relative to MVA was 50\%. All the results were based on averages and they are set out in Table 1.

TABLE 1 MVA $V S$. OTHER FINANCIAL PERFORMANCE MEASURES

$\begin{array}{lc}\text { Correlation with MVA } & \mathbf{r}^{\mathbf{2}} \\ \text { EVA } & 50 \% \\ \text { ROE } & 25 \% \\ \text { Cash flow growth } & 22 \% \\ \text { EPS growth } & 18 \% \\ \text { Asset growth } & 18 \% \\ \text { Dividend growth } & 16 \% \\ \text { Turnover growth } & 9 \% \\ \text { Source: Adapted from Stern (1993:36) } & \end{array}$

\section{B. Uyemura et al. - EVA and wealth creation}

Uyemura $^{2}$ et al. (1996:98) used a sample of the 100 largest US banks for the ten-year period from 1986 to 1995 to calculate MVA and to test the correlation with EVA, as well as four other accounting measures, namely net income (amount), EPS, ROE and ROA. The results of their regression analysis are set out in Table 2 .

\begin{tabular}{ll}
\multicolumn{2}{c}{ TABLE 2 CORRELATION OF DIFFERENT PERFORMANCE MEASURES WITH } \\
SHAREHOLDER WEALTH \\
Performance measure & $\mathbf{r} 2$ \\
EVA & $40 \%$ \\
ROA & $13 \%$ \\
ROE & $10 \%$ \\
Net income (amount) & $8 \%$ \\
EPS & $6 \%$
\end{tabular}

Source: Uyemura et al. (1996:98)

The analysis above clearly shows that EVA is the measure that correlates the best by far

With shareholder wealth creation. In an alternative approach where changes in the performance measures were regressed against standardized MVA, the results were not very different. Standardized EVA (EVA divided by capital) again had an $\mathrm{r} 2$ of $40 \%$, while for ROA it was $25 \%$, for ROE it was $21 \%$, for net income it was $3 \%$ and for EPS it was $6 \%$.

C. Milunovich and Tsuei's study on the use of EVA and MVA in the US computer industry

Milunovich and Tsuei $^{3}$ (1996:111) investigated the correlation between frequently used

Financial measures (including EVA) and the MVA of companies in the US computer technology industry (so-called 'server-vendors') for the period from 1990 to 1995. The results of their study are set out in Table 3.

TABLE 3 CORRELATION OF DIFFERENT PERFORMANCE MEASURES WITH MVA IN THE US

\section{Computer technology industry}

Performance measure r2

EVA r2

EPS growth

ROE

$34 \%$

Free cash growth

$29 \%$

FCF

$25 \%$

$18 \%$

Source: Milunovich and Tsuei (1996:111) 
Clearly EVA demonstrated the best correlation and it would be fair to infer that a company that can consistently improve its EVA should be able to boost its MVA and therefore its shareholder value. Milunovich and Tsuei (1996:111) argue that the relatively weak correlation between MVA and FCF is due to the fact that FCF can be a misleading indicator. They point out that a fast-growing technology start-up company with positive EVA investment opportunities and a loss-making company on the verge of bankruptcy can have similar negative cash flows. They concluded that growth in earnings is not enough to create value, unless returns are above the cost of capital. They are of the opinion that EVA works best as a supplement to other measures when one is evaluating shares and that EVA sometimes works when other measures fail.

\section{Dodd and Chen's investigation of the explanatory power of EVA}

Dodd and Chen ${ }^{4}$ (1996:27) used the 1992 Stern Stewart 1000 database as a starting point

And added some supplementary data for the ten years from 1983 to 1992 . They gathered

Complete data for 566 US companies and set out to test the claim that EVA is a superior

Measure of shareholder value performance. Although they did find a correlation between share returns and EVA (an r2 of $20 \%$ ), it was not as high as the $\mathrm{r} 2$ of share returns and ROA, for which the $\mathrm{r} 2$ was $25 \%$. The $\mathrm{r} 2$ for the other accounting measures tested, namely EPS and ROE, was very low (between $5 \%$ and $7 \%$ ). Based on the data for this large number of companies over as long a period as 10 years, it appears that EVA does not relate well to share returns. The results that Dodd and Chen (1996) obtained imply that $80 \%$ of changes in share returns could not be accounted for by changes in EVA. In their study (bearing in mind that unadjusted data were used), the ROA displayed a better explanatory ability than EVA did. Dodd and Chen (1996:27) also found that residual income, which is similar to EVA, except for the adjustments required to deal with the so-called accrual accounting distortions, gave results almost identical to those achieved using EVA. The r2 of residual income relative to share returns was $19 \%$, compared to EVA's r2 of $20 \%$. Even when more complete multiple regression models

TABLE 1: EMPIRICAL ANALYSIS ON HUL LTD DURING 1999-2009:

\begin{tabular}{|c|c|c|c|c|c|c|c|c|c|c|c|}
\hline Particulars & $\mathbf{1 9 9 9}$ & $\mathbf{2 0 0 0}$ & $\mathbf{2 0 0 1}$ & $\mathbf{2 0 0 2}$ & $\mathbf{2 0 0 3}$ & $\mathbf{2 0 0 4}$ & $\mathbf{2 0 0 5}$ & $\mathbf{2 0 0 6}$ & $\mathbf{2 0 0 7}$ & $\mathbf{2 0 0 8}$ & $\mathbf{2 0 0 9}$ \\
\hline 1. Debt & 162 & 93 & 50 & 45 & 881 & 1588 & 360 & 163 & 170 & 150 & 180 \\
\hline 2. Equity & 1908 & 2296 & 2766 & 3351 & 2899 & 2116 & 2200 & 2515 & 2700 & 2450 & 2600 \\
\hline 3. Capital Employed & 2070 & 2389 & 2816 & 3396 & 3780 & 3704 & 2560 & 2678 & 2870 & 2600 & 2780 \\
\hline 4. Cost of Debt (\%) & 8.61 & 8.46 & 7.72 & 6.45 & 4.88 & 5.19 & 3.38 & 5.9 & 6.0 & 5.4 & 5.8 \\
\hline
\end{tabular}

were used, the results for the two measures were almost the same. The $\mathrm{r} 2$ for EVA-based measures was $41 \%$, compared to a similar $\mathrm{r} 2$ of $41 \%$ for residual income-based measures. Dodd and Chen (1996) concluded that EVA and residual income performance measurement systems would, in general, yield similar results.

\section{Objectives:}

1) To calculate the EVA and Traditional Performance measures like ROCE, EPS, RONW of Hindustan Unilever Limited.

2) To compare EVA with the Traditional methods for evaluating a company's Financial Performance.

\section{SOURCE OF DATA}

The secondary data has been collected from published annual reports of HINDUSTAN UNILEVER LIMITED; relevant information has been collected from other publications.

Tools of Analysis:

$\mathrm{EVA}=$ NOPAT $-\mathrm{COCE}$

NOPAT $=$ Net operating profits after tax

$\mathrm{COCE}=\mathrm{W}_{1} \cdot \mathrm{K}_{\mathrm{d}}+\mathrm{W}_{2} \cdot \mathrm{K}_{\mathrm{e}}+\mathrm{W}_{3} \cdot \mathrm{K}_{\mathrm{r}}$

$\mathrm{W}_{1}, \mathrm{~W}_{2}, \mathrm{~W}_{.3}=$ Weights assigned to individual sources in the capital structure

$\mathrm{K}_{\mathrm{d}} \quad=\mathrm{I}(1-\mathrm{t})$

$\mathrm{K}_{\mathrm{d}}=$ Cost of Debt

$\mathrm{I}=$ Interest rate

$\mathrm{t}=$ tax rate

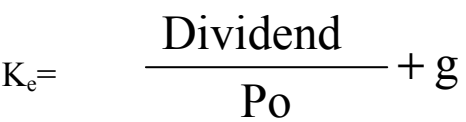

$\mathrm{K}_{\mathrm{e}}=$ Cost of Equity

$\mathrm{P}_{\mathrm{o}}=$ Price of share

$\mathrm{G}=$ growth in a share

$\mathrm{g}=\mathrm{K}_{\mathrm{e}} \mathrm{X}$ Retention Ratio (b)

$\mathrm{b}=$

Earnings Per Share - Dividend Per Share Earnings Per Share 


\begin{tabular}{|c|c|c|c|c|c|c|c|c|c|c|c|}
\hline 5.Cost of Equity & 19.7 & 19.7 & 16.7 & 14.4 & 12.96 & 14.77 & 15.5 & 16.38 & 17.01 & 16.03 & 16.23 \\
\hline $\begin{array}{l}\text { 6. Weighted Average } \\
\text { Cost of Capital \% } \\
\text { (WACC) }\end{array}$ & 18.8 & 19.27 & 16.54 & 14.3 & 11.07 & 10.66 & 13.8 & 15.74 & 15.26 & 15.96 & 16.16 \\
\hline 7.COCE $(3 * 6)$ & 389 & 460.3 & 465.7 & 485.6 & 418.4 & 394.8 & 353.2 & 421.5 & 438.0 & 415.0 & 424.0 \\
\hline $\begin{array}{l}\text { 8.Profit After Tax, } \\
\text { before exceptional } \\
\text { items }\end{array}$ & 1084 & 1310 & 1541 & 1716 & 1804 & 1199 & 1355 & 1540 & 1743 & 2501 & 2605 \\
\hline $\begin{array}{l}\text { 9.Add: Interest, after } \\
\text { taxes }\end{array}$ & 14 & 8 & 5 & 6 & 43 & 82 & 12 & 7 & 9 & 11 & 13 \\
\hline $\begin{array}{l}\text { 10.Net operating } \\
\text { profits After } \\
\text { Taxes(NOPAT) }\end{array}$ & 1098 & 1318 & 1546 & 1722 & 1847 & 1281 & 1367 & 1547 & 1752 & 2512 & 2650 \\
\hline $\begin{array}{l}\text { 11. COCE, as per(7) } \\
\text { above }\end{array}$ & 390 & 460 & 466 & 486 & 418 & 395 & 353 & 421 & 438.0 & 415 & 424.0 \\
\hline 12.EVA(10-11) & 708 & 858 & 1080 & 1236 & 1429 & 886 & 1014 & 1126 & 1314 & 2097 & 2226 \\
\hline
\end{tabular}

Source: Data collected from Annual reports of HUL Ltd

\section{Interpretation:}

From the above table1, it can be inferred that the company has been adding value to the shareholders during the study period (1999-2009). The calculation of EVA depends on the calculation of the components of the EVA. The major components of EVA are NOPAT and COCE. The EVA of the company has been increased from Rs. 708Crores for the year 1999 to Rs.2226Crores for the year 2009, indicating the good economic earning capacity of the company. But there was a fall of Rs. 533Crores in EVA from the year 2003 to the year 2004; due to fall in NOPAT as it paid more interest (Rs.82Crores) on additional debt (Rs. 1588Crores).there after the company's EVA was again increasing trend and it was touched to Rs.2226crores by the year 2009.

\section{EVA Vs. Traditional Conventional MeAsures}

TABLE 2: EVA VS ROCE AND EVA VS RONW AND EVA VS EPS

\begin{tabular}{|c|c|c|c|c|c|c|c|}
\hline Year & $\begin{array}{c}\text { EVA } \\
\text { (in } \\
\text { Crores) }\end{array}$ & $\begin{array}{c}\text { ROCE } \\
\mathbf{( \% )}\end{array}$ & $\begin{array}{c}\text { RONW } \\
\mathbf{( \% )}\end{array}$ & $\begin{array}{c}\text { EPS } \\
\text { (in } \\
\text { Crs) }\end{array}$ & $\begin{array}{c}\text { EVA as a \% } \\
\text { of Capital } \\
\text { Employed }\end{array}$ & $\begin{array}{c}\text { EVA as } \\
\text { a of } \\
\text { Net } \\
\text { Worth }\end{array}$ & $\begin{array}{c}\text { EVA as a \%o of } \\
\text { No. of shares } \\
\text { outstanding }\end{array}$ \\
\hline 1999 & 694 & 61.8 & 50.9 & 4.86 & 30.43 & 32.99 & 3.15 \\
\hline 2000 & 858 & 64.6 & 52.6 & 5.95 & 33 & 34.48 & 3.89 \\
\hline 2001 & 1080 & 62.4 & 53.9 & 7.46 & 34.53 & 35.48 & 5.22 \\
\hline 2002 & 1236 & 59.4 & 48.4 & 8.04 & 33.25 & 33.78 & 5.74 \\
\hline 2003 & 1429 & 60.2 & 82.8 & 8.05 & 37.18 & 66.81 & 6.37 \\
\hline 2004 & 886 & 45.9 & 57.2 & 5.44 & 24.86 & 42.33 & 4.01 \\
\hline 2005 & 1014 & 68.7 & 61.1 & 6.40 & 42.91 & 43.97 & 4.79 \\
\hline 2006 & 1126 & 67.0 & 68.1 & 8.41 & 40.27 & 41.34 & 6.15 \\
\hline 2007 & 1314 & 78.0 & 80.1 & 8.73 & 86 & 91.29 & 6.60 \\
\hline 2008 & 2097 & 107.5 & 103.6 & 11.46 & 84.43 & 101.72 & 9.61 \\
\hline 2009 & 2226 & 76.0 & 86.4 & 12.45 & 80.07 & 91.70 & 9.93 \\
\hline
\end{tabular}

\section{Interpretation:}

From the above table 2, it was observed that HUL Ltd. depicts a rosy picture in terms of Return on Capital Employed, Return on Net worth and EPS. In the year 1999, ROCE is $61.8 \%$ i.e., for every Rs 100 investment the return is Rs 61.8, where as EVA as a \% of Capital Employed is only 30.43 i.e., for every Rs 100 investment, the company has added value of Rs 30.43.On an average, the Return on Capital Employed during the study period is $62.4 \%$ whereas average EVA as a \% of Capital Employed is 33.25\%. In the year 1999, 
RONW is $50.9 \%$ i.e., for every Rs 100 investment the return is Rs 50.9, whereas EVA as a \% of Net Worth is only 32.99 i.e., for every Rs 100 investment, the company has added value of Rs 32.99. In the year 1999, EPS was $4.86 \%$ i.e., for every Rs 100 investment the return is Rs 4.86, whereas EVA as a $\%$ of Outstanding shares is only 3.15 i.e., for every Rs100 investment, the company has added value of Rs 3.15. Thus the comparison shows that divergence exists between the performance results given by traditional methods and EVA. The traditional measures do not reflect the real value addition to shareholder's wealth.

$\begin{array}{lc}\begin{array}{r}\text { TABLE } 3 \text { COEFFICIENT OF CORRELATION OF DIFFERENT PERFORMANCE } \\ \text { MEASURES WITH SVA }\end{array} \\ \text { Performance measure } & \mathbf{r} \\ \text { EVA } & 84 \% \\ \text { ROCE } & 45 \% \\ \text { RONW } & 37 \% \\ \text { EPS } & 26 \%\end{array}$

The above table 3, clearly shows that EVA is the measure that correlates the best by far With shareholder wealth creation and it would be fair to infer that a company that can consistently improve its EVA should be able to boost its shareholder value. It is also identified that the relatively weak correlation that was existing between SVA (Shareholder Value Added) and ROCE, RONW as well as EPS. They concluded that growth in earnings is not enough to create value, unless returns are above the cost of capital. They are of the opinion that EVA works best as a supplement to other measures when one is evaluating shares and that EVA sometimes works when other measures fail.

\section{CONCLUSION}

From the analysis, it is clearly observed that EVA, when compared with traditional measures, it gives exact figures how much really the shareholder is going to get at the end of the accounting year by considering cost of capital like cost of equity, cost of debt, cost of retained earnings. Hence I conclude that EVA is the best appropriate measure for measuring the value of shareholders.

\section{REFERENCES}

[1] Stern, J, “The EVA Challenges, “New York: John Willey \& Sons, 1993, pp. 25-35.

[2] Uyemura, D. G., C. C. Kantor and J. M. Petit, "EVA for Banks: Value Creation, Risk Management and Profitability Measurement," Journal of Applied Corporate Finance, 9(2), 1996, pp. 94-111.

[3] Milunovich, S. and A. Tsuei, "EVA in the Computer Industry," Journal of Applied Corporate Finance, 9(2), 1996 pp. 104-115.

[4] Chen, S. and J. L. Dodd, "Economic Value Added: An Empirical Examination of a New Corporate Performance Measure," Journal of Managerial Issues, 9(3), 1996, pp. 318-333. 